\title{
Photoperiod, Temperature, and Plant Age Interact to Affect Short-day Onion Cold Hardiness
}

\author{
D.F. Warnock and W.M. Randle \\ Department of Horticulture, University of Georgia, Athens, GA 30602
}

O.M. Lindstrom, Jr.

Department of Horticulture, University of Georgia, Griffin Experiment Station, Griffin, GA 30223

Additional index words. Allium cepa, $\mathrm{LT}_{50}$, ethylene glycol

\begin{abstract}
Proper acclimation of onion (Allium cepa L.) seedlings can enhance winter freeze survival; therefore, the effects of photoperiod-temperature combinations, photoperiod, and plant age on the cold hardiness of short-day onions were investigated. Following acclimation at various photoperiod-temperature regimes, different-aged plants were frozen to various subzero temperatures in an ethylene glycol bath and evaluated for cold hardiness. Older plants were more cold hardy than younger plants. An 11-hour photoperiod-decreasing temperature $(20 / 15$ to $10 / 5 \mathrm{C}$ day/night) treatment improved plant cold hardiness over other photoperiod-temperature regimes. Various photoperiods (8-, 11-, 14-, and 24-hour) applied during a 14-day, 3C acclimation treatment before freezing had little effect on plant cold hardiness. However, day 7 foliar and day 14 root evaluations indicated that 81-day-old plants given an 8- or 11-hour photoperiod during the $3 \mathrm{C}$ acclimation treatment were less cold hardy than older plants (91 or 112 days) given the same acclimation photoperiod.
\end{abstract}

Commercial short-day onion cultivars normally are seeded or transplanted in the fall, overwintered, and harvested in the spring (Corgan and Kedar, 1990). Onions are lost often to cold stress when overwintered. Thus, in some areas of the United States, transplants are used in late winter or early spring. In Georgia, winter temperatures can fluctuate from-16 to 37C (Ruffner and Bair, 1985), and yearly onion losses can exceed 50\% (Berry, 1983). In Georgia, fall transplanting of onion seedlings into the field is preferred over direct seeding (Grandberry et al., 1990), since older plants are more cold hardy than younger ones (Børtnes and Opshal, 1983; Peffley et al., 1981). Transplanting, however, does not eliminate freeze damage to seedlings during extreme winter weather.

Laboratory methods were developed to evaluate onion cold hardiness. Field-acclimated short-day onions were frozen to $-14 \mathrm{C}$ in a commercial freezer to determine the temperature required to kill $50 \%$ of the plants $\left(\mathrm{LT}_{50}\right)$ (Peffley et al., 1981). Børtnes and Opshal (1983), using plant survival percentages, determined that temperatures between -5 and $-6 \mathrm{C}$ were best for separating differences in cold hardiness among cultivars when field-acclimated long-day onions were frozen bare-root from -3 to $-7 \mathrm{C}$. In addition, plants acclimated in growth rooms responded similarly to fieldacclimated plants, although lower acclimation

Received for publication 9 Nov. 1992. Accepted for publication 1 June 1993. The cost of publishing this paper was defrayed in part by the payment of page charges. Under postal regulations, this paper therefore must be hereby marked advertisement solely to indicate this fact. temperatures imparted greater cold hardiness. Rivera-Figueroa (1991) reported that high soilmoisture levels reduced freeze injury in potted field-grown onions. Martin and Ingram (1992) reported that the soil's heat capacity insulated plants from temperature changes. Thus, it was unclear if the reduced injury reported by RiveraFigueroa (1991) resulted from increased hardiness or buffered temperature changes.

Benefits of increased short-day onion cold tolerance include greater winter survival, the ability to direct seed, reduced production costs, and improved crop quality. Because little is known about how the environment interacts with short-day onions to influence plant cold hardiness, we investigated the effects of various acclimation regimes and plant age.

Photoperiod-temperature regime and plant age. During the 1991-92 growing season (October to May), 'Granex 33' seed (Asgrow Seed, Kalamazoo, Mich.) were sown on two dates 14 days apart in 8.1-liter $(52.2 \times 25.9 \times$ $6.0 \mathrm{~cm}$ ) flats of Fafard 3B medium (Fafard, Anderson, S.C.) to obtain plants of two ages (90 and 104 days) for freezing. Seeds were germinated and seedlings were greenhousegrown under an 11-h photoperiod with a day/ night cycle set at $28 / 16 \mathrm{C}$. Fertilization consisted of weekly applications of 20N-8.7P16.6K (Grace-Sierra, Milpitas, Calif.) with $150 \mathrm{mg} \mathrm{N} /$ liter for 5 weeks followed by 250 $\mathrm{mg} \mathrm{N} /$ liter before or just after seedlings were transplanted and placed into growth chamhers. Sixty uniform seedlings of each age (33 or 47 days) were transplanted on 2-cm centers in 8.2-liter $(31.8 \times 29.2 \times 8.9 \mathrm{~cm})$ wooden flats of the soilless medium and placed into growth chambers (model E15; Conviron, Henderson, N.C.) with an 11-h photoperiod and a day/ night cycle of $20 / 15 \pm 0.5 \mathrm{C}$. Once in growth chambers, plants received $250 \mathrm{mg} \mathrm{N} /$ liter until 14 days before applying a 3C prefreeze treatment. The design was a split plot with six replications. Photoperiod-temperature (PT) regimes were main plots and plant ages were subplots. Twenty-eight days after the plants were transplanted and placed into the growth chambers, PT treatments were applied for 17 days (Table 1). Thereafter, 60 plants from each PT-plant age combination remained in the growth chambers as controls. The remaining 120 plants in each combination were placed in a $3 \pm 1 \mathrm{C}$ cooler for 11 days, continuing the same photoperiod (8-or 11-h) used during the PT treatments. During dark periods, black plastic-covered boxes were placed over the plants for the appropriate duration. Fluorescent and incandescent lighting averaged 16 $\mu \mathrm{mol} \cdot \mathrm{m}^{-2} \cdot \mathrm{s}^{-1}$ photosynthetic photon flux at canopy height.

Following 3C treatment, treated and control plants were harvested, cleaned, graded to a uniform size (5 to $10 \mathrm{~mm}$ pseudostem diameter), and held in $3 \pm 3 \mathrm{C}$ coolers for $2 \mathrm{~h}$ before freezing. Each replication consisted of 15 plants from each PT-plant age combination. Three plants from each replication were wrapped in cheesecloth, wetted, and placed in a $25 \times 150$ $\mathrm{mm}$ test tube for freezing in an ethylene glycol bath (model 2425; Forma Scientific, Marietta, Ohio) as described by Palta et al. (1977). A data logger (model CR7X; Campbell Scientific, Logan, Utah) monitored temperatures via copper-constantan thermocouples near the meristem region. At $-2 \mathrm{C}$, tubes were nucleated with an ice crystal and maintained at this temperature overnight. Temperatures were lowered $2 \mathrm{C} / \mathrm{h}$, and tubes for each PT-plant age combination were removed at $-3,-6,-9$, and $-12 \mathrm{C}$. Plants in tubes held at $4 \pm 1 \mathrm{C}$ were used as a nonfrozen control. Frozen plants were thawed at $4 \pm 1 \mathrm{C}$ overnight, replanted, and placed in a greenhouse with an 11-h photoperiod and a day/night cycle set at 28/16C. Seven and 14 days after replanting, foliage was scored visually as alive or dead. Root plates also were scored as alive or dead based on root regeneration 14 days after replanting. $\mathrm{LT}_{50}$ values, determined using the Spearman-Kärber

Table 1. Eight photoperiod-temperature (PT) and plant age combinations used to acclimate shortday onion before cold hardiness assessment.

\begin{tabular}{lcr}
\hline $\begin{array}{l}\text { Photoperiod }(\mathrm{h}) \times \\
\text { temp }\left({ }^{\circ} \mathrm{C}, \mathrm{d} / \mathrm{n}\right)^{\mathrm{z}}\end{array}$ & $\begin{array}{c}\text { PT } \\
\text { code }^{\mathrm{y}}\end{array}$ & $\begin{array}{c}\text { Plant age } \\
\text { (days) }\end{array}$ \\
\hline $11 \times 20 / 15$ & 1 & 90 \\
& 1 & 104 \\
$11 \times 20 / 15$ & 2 & 90 \\
to $11 \times 10 / 5$ & 2 & 104 \\
$11 \times 20 / 15$ & 3 & 90 \\
to $8 \times 20 / 15$ & 3 & 104 \\
$11 \times 20 / 15$ & & \\
to $8 \times 10 / 5$ & 4 & 90 \\
& 4 & 104 \\
\hline
\end{tabular}

Plants had a 28-day adjustment period at PT-1 before other PT treatments were applied for 17 days; $\mathrm{d} / \mathrm{n}=$ day/night.

yPT $-1,-2,-3$, and $-4=$ PT treatments one, two, three, and four, respectively. 
method (Bittenbender and Howell, 1974), were tested using the GLM procedure of SAS (SAS Institute, Cary, N.C.). Because onions have step responses to photoperiod (bulbing) and temperature (vernalization), LSD mean separations were performed.

Plants preconditioned at $3 C$. Foliar and root $\mathrm{LT}_{50}$ values were affected by PT treatment and plant age when plants were held at $3 \mathrm{C}$ before freezing (Table 2). $\mathrm{LT}_{50}$ values were lower at day 7 than at day 14, indicating some plants that initially were scored as alive at day 7 had died by day 14. PT-2 resulted in greater foliar and root cold hardiness than the other PT treatments. Older plants (104 days) were more cold hardy than younger plants ( 90 days), as reflected by the lower foliar and root $\mathrm{LT}_{50}$ values for older plants. The PT treatment $x$ plant age interaction significantly affected foliar $\mathrm{LT}_{50}$ values at day 7 and 14 in plants receiving a $3 \mathrm{C}$ treatment (Table 2 ). Older plants given a $3 \mathrm{C}$ treatment were more cold hardy than younger plants for all PT regimes (Fig. 1A).

Plants not preconditioned at 3C. When plants were not exposed to $3 \mathrm{C}$ before freezing, foliar and root $\mathrm{LT}_{50}$ values also were affected by PT treatments (Table 2). Foliage from PT2 and PT-4 was more cold hardy than foliage

Table 2. Foliar and root $\mathrm{LT}_{50}$ values $\left({ }^{\circ} \mathrm{C}\right)$ from evaluations 7 and 14 days after freezing to $-12 \mathrm{C}$ following photoperiod-temperature (PT) treatments of different-aged (days from seeding) onion plants with and without 11 days of prefreeze $3 \mathrm{C}$ conditioning.

\begin{tabular}{|c|c|c|c|}
\hline \multirow[b]{2}{*}{ Treatment $^{y}$} & \multicolumn{2}{|c|}{ Foliar $\mathrm{LT}_{50}$ rating $^{2}$} & \multirow{2}{*}{$\begin{array}{r}\text { Root LT } \\
\text { rating } \\
\text { (day 14) }\end{array}$} \\
\hline & Day 7 & Day 14 & \\
\hline \multicolumn{4}{|c|}{ Conditioned } \\
\hline \multicolumn{4}{|l|}{ PT treatment ${ }^{x}$} \\
\hline 1 & -7.6 & -3.4 & -0.8 \\
\hline 2 & -10.2 & -6.5 & -2.5 \\
\hline 3 & -6.3 & -2.2 & -0.7 \\
\hline 4 & -6.0 & -3.1 & -0.8 \\
\hline $\begin{array}{l}\mathrm{LSD}_{0.05} \\
\text { Plant age (days) }\end{array}$ & 0.7 & 0.7 & 0.5 \\
\hline 90 & -6.5 & -2.5 & -0.5 \\
\hline 104 & -8.5 & -5.1 & -1.8 \\
\hline \multicolumn{4}{|l|}{ Significance } \\
\hline PT & ** & ** & ** \\
\hline Plant age (A) & $* *$ & ** & ** \\
\hline $\mathrm{PT} \times \mathrm{A}$ & NS & $* *$ & NS \\
\hline \multicolumn{4}{|c|}{ Nonconditioned } \\
\hline \multicolumn{4}{|l|}{ PT treatment } \\
\hline 1 & -7.3 & -3.8 & -1.5 \\
\hline 2 & -11.0 & -9.7 & -2.8 \\
\hline 3 & -7.7 & -4.8 & -1.5 \\
\hline 4 & -10.5 & -7.7 & -1.8 \\
\hline $\operatorname{LSD}_{0.05}$ & 2.0 & 2.2 & 0.9 \\
\hline \multicolumn{4}{|l|}{ Plant age (days) } \\
\hline 90 & -9.0 & -5.5 & -1.8 \\
\hline 104 & -9.3 & -7.5 & -2.0 \\
\hline \multicolumn{4}{|l|}{ Significance } \\
\hline PT & ** & ** & * \\
\hline Plant age (A) & NS & ** & NS \\
\hline $\mathrm{PT} \times \mathrm{A}$ & NS & ** & NS \\
\hline
\end{tabular}

${ }^{2} \mathrm{LT}_{50}=$ lethal temperature for $50 \%$ kill.

'Plants had a 28-day adjustment period at PT-1 before PT treatments were applied.

${ }^{x}$ See Table 1 for explanation.

NS.***NNonsignificant or significant at $P \leq 0.05$ or 0.01 , respectively. from PT-1 or PT-3, and roots of PT-2 also were more cold hardy than roots from the other PT treatments. The PT treatment $\times$ plant age interaction significantly affected foliar $\mathrm{LT}_{50}$ values at day 14 in plants not given a 3C treatment (Table 2). Plant age did not affect the cold tolerance of plants from PT-1 or PT-3 acclimation regimes; however, older plants were significantly more cold hardy than younger plants given PT-2 or PT-4 (Fig. 1B). For each PT treatment, plants not exposed to $3 \mathrm{C}$ before freezing were either as cold hardy as plants exposed to $3 \mathrm{C}$ for 11 days or more cold hardy. Thus, significant acclimation occurred during the PT treatments without the additional 3C exposure. Børtnes and Opshal (1983) reported long-day onions hardened at $3 \mathrm{C}$ were more cold hardy than plants hardened at $5 \mathrm{C}$. In our study, control plants given the PT treatments may have been larger (older) and therefore more cold hardy when frozen, since little growth occurs at 3C (Brewster, 1990), and larger plants are more cold hardy than younger plants (Larsen, 1978; Peffley et al., 1981).

Photoperiods during cold acclimation and plant age. 'Grand Prix' seed (Sun Seeds, Hollister, Calif.) were sown on three dates and thinned to obtain 80 seedlings each of three ages $(81,91$, and 112 days) per 8.1-liter flat. Greenhouse cultural procedures were as described in the PT-plant age experiment. The design was a split plot with three replications. Main plots were photoperiod and subplots were plant age. The different-aged plants were acclimated at $3 \pm 1 \mathrm{C}$ and 8-, 11-, 14-, or 24-h photoperiods for 14 days. Plants then were harvested, frozen at $2 \mathrm{C} / \mathrm{h}$ to $-12 \mathrm{C}$, removed at $3 \mathrm{C}$ intervals, thawed, and evaluated for cold hardiness at 7 and 14 days after replanting, as in the first experiment.

Foliar $\mathrm{LT}_{50}$ values were affected signifi- cantly by photoperiod. Plants from an 8-h photoperiod were least cold hardy. Plants under this photoperiod, however, were stressed before freezing due to foliar Botrytis infection, which may have contributed to the higher $\mathrm{LT}_{50}$ values. There was no significant difference in day $7 \mathrm{LT}_{50}$ values of plants provided 11- and 14-h photoperiods. Plants from the 24-h photoperiod were most cold hardy (Table 3 ). $\mathrm{LT}_{50}$ values were not affected by 11-, 14- or 24-h photoperiods at day 14 foliar evaluations. Cold hardiness was influenced significantly $(P \leq$ $0.01)$ by plant age for foliar and root $\mathrm{LT}_{50}$ evaluations (Table 3). Hardiness increased with increasing plant age from 81 to 112 days, The photoperiod $\times$ age interaction significantly affected foliar (day 7) and root (day 14) $\mathrm{LT}_{50}$ values (Fig. 2). Higher day 7 (Fig. 2A) and day 14 (Fig. 2B) $\mathrm{LT}_{50}$ values indicated that younger (81 days) plants were less cold hardy than older (112 days) plants following an 8- or 11-h photoperiod, 3C prefreeze treatment. $\mathrm{LT}_{50}$ values 7 days after freezing different-aged plants did not differ when plants were given longer (14- or 24-h) photoperiods (Fig. 2A). However, roots of older (112 days) plants were more cold hardy (lower $\mathrm{LT}_{50}$ values) than those of younger (81 days) plants when given the longer photoperiods (Fig. 2B). Unhardened control plants maintained under greenhouse conditions were killed at an average of $-0.8 \mathrm{C}$ when frozen.

Our root $\mathrm{LT}_{50}$ values were much higher than values reported by others; $-10.8 \mathrm{C}$ by Peffley et al. (1981) and $-14.8 \mathrm{C}$ by RiveraFigueroa (1991). This discrepancy may be explained by differences in the freezing techniques used. With our system, freezing in liquid provided more uniform freezing temperatures (Larsen, 1978); monitoring with thermocouples ensured that the desired tempera-

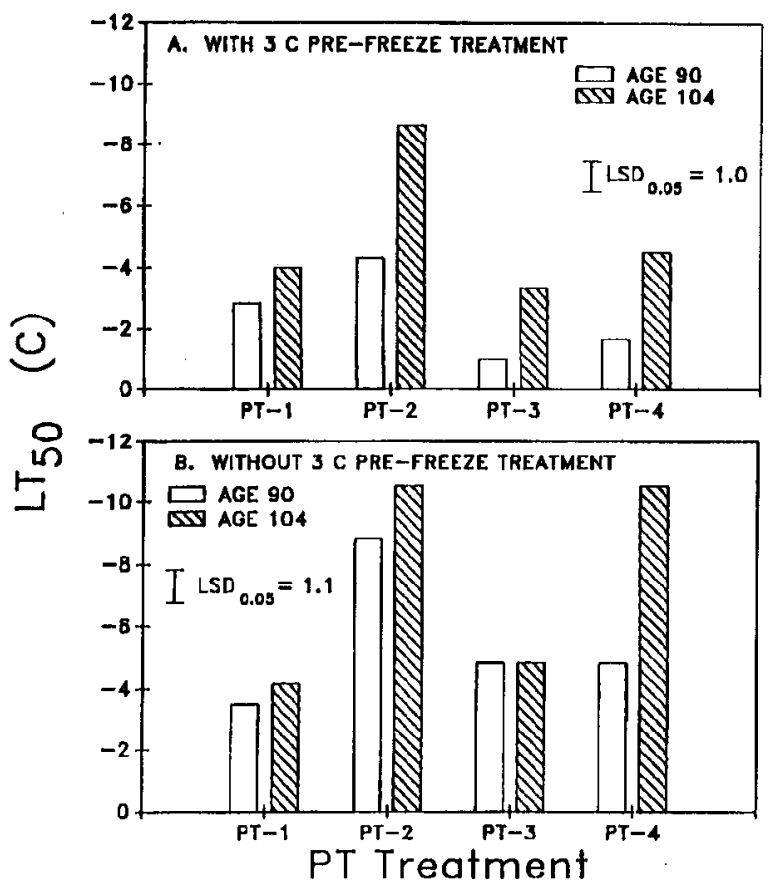

Fig. 1. Lethal temperature $\left(\mathrm{LT}_{50}\right)$ values for photoperiod-temperature $(\mathrm{PT}) \times$ plant age (days from seeding) interactions. Plants (A) with and (B) without an 11-day prefreeze treatment at $3 \mathrm{C}$ were evaluated 14 days after freezing to $-12 \mathrm{C}$. PT-1, $-2,-3$, and -4 : See Table 1 for explanation. 
Table 3. Foliar and root $\mathrm{LT}_{50}\left({ }^{\circ} \mathrm{C}\right)$ values for evaluations 7 and 14 days after freezing to $-12 \mathrm{C}$ following different photoperiod treatments for different-aged (days from seeding) onions during 14 days of $3 \mathrm{C}$ prefreeze conditioning.

\begin{tabular}{|c|c|c|c|}
\hline \multirow[b]{2}{*}{ Treatment } & \multicolumn{2}{|c|}{ Foliar $\mathrm{LT}_{50}$ rating $^{\mathbf{2}}$} & \multirow{2}{*}{$\begin{array}{c}\text { Root } \mathbf{L T} \\
\text { rating }^{\mathbf{z}} \\
\text { day } 14\end{array}$} \\
\hline & Day 7 & Day 14 & \\
\hline \multicolumn{4}{|l|}{ Photoperiod (h) } \\
\hline 8 & -4.1 & -1.8 & -1.1 \\
\hline 11 & -5.3 & -3.7 & -1.7 \\
\hline 14 & -5.7 & -3.2 & -1.8 \\
\hline 24 & -6.6 & -3.5 & -2.6 \\
\hline $\mathrm{LSD}_{0.05}$ & 0.7 & 1.5 & 1.8 \\
\hline \multicolumn{4}{|l|}{ Plant age (days) } \\
\hline 81 & -3.7 & -1.4 & +0.1 \\
\hline 91 & -6.2 & -3.0 & -2.2 \\
\hline 112 & -6.4 & -4.8 & -3.3 \\
\hline $\mathrm{LSD}_{0.05}$ & 1.0 & 1.0 & 0.6 \\
\hline \multicolumn{4}{|l|}{ Significance } \\
\hline Photoperiod (P) & $* *$ & NS & NS \\
\hline Plant age (A) & $* *$ & $* *$ & $* *$ \\
\hline $\mathbf{P} \times \mathbf{A}$ & $*$ & NS & $*$ \\
\hline
\end{tabular}

${ }^{\mathrm{z}} \mathrm{TT}_{50}=$ lethal temperature for $50 \%$ kill.

NS, **NNonsignificant or significant at $P \leq 0.05$ or 0.01 , respectively.

ture was achieved; nucleation prevented the possibility of supercooling (Palta et al., 1977); and using test tubes reduced temperature buffering due to soil's higher heat capacity. A second explanation for our higher $\mathrm{LT}_{50}$ values may be that the acclimation regimes applied were not as rigorous as field acclimation. However, cold tolerance of field-acclimated plants and artificially acclimated plants was well correlated (Børtnes and Opshal, 1983).

Root $\mathrm{LT}_{50}$ values were significantly higher than foliar $\mathrm{LT}_{50}$ values in this study. The root plate was the least cold-hardy onion organ (Sakai and Yoshie, 1984). Root cold hardiness is critical. When root regeneration occurs, the plant will likely survive cold stress. Foliar cold hardiness is also important in onions. High levels of foliar cold hardiness may ensure uninterrupted growth and development during winter by reducing the amount of foliage lost due to repeated cold damage. Healthy foliage would conserve assimilates and ensure adequate plant canopy size for rapid spring growth.

Onion cold hardiness was affected by environmental and physiological factors. The 11-h photoperiod-decreasing temperature $(20 / 15$ to 10/5C day/night) treatment provided greater cold hardiness than other PT treatments. Photoperiod length during 14 days of 3C acclimation had little effect on the cold hardiness of

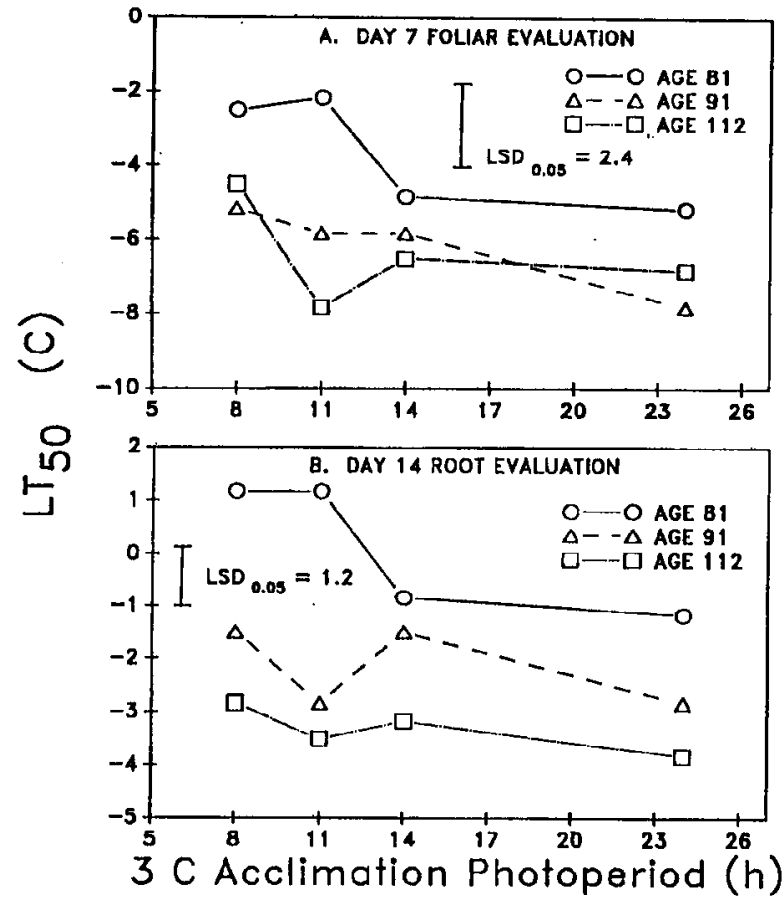

Fig. 2. Lethal temperature $\left(\mathrm{LT}_{50}\right)$ values for photoperiod $\times$ plant age (days from seeding) interaction on $(\mathbf{A})$ foliar damage 7 days and $(B)$ root damage 14 days after freezing. Onion plants were frozen to $-12 \mathrm{C}$ following a 14-day, 3C prefreeze treatment before evaluating cold damage.

roots once frozen. However, photoperiod duration during the $3 \mathrm{C}$ acclimation affected foliar cold hardiness. Older plants were more cold hardy regardless of acclimation regime. Greater plant age (size) sometimes appeared to substitute for exposure to $3 \mathrm{C}$ in providing increased seedling cold hardiness.

\section{Literature Cited}

Berry, D. (publisher). 1983. Cold damages $75 \%$ of Vidalia onion crop. The Atlanta Constitution, Atlanta, Ga. 116(138):13

Bittenbender, H.C. and G.S. Howell. 1974. Adaptation of the Spearman-Kärber method for estimating the $\mathrm{T}_{50}$ of cold stressed flower buds. J. Amer. Soc. Hort. Sci. 99:187-190.

Børtnes, G. and B. Opshal. 1983. Winter survival, freezing tolerance and hardening in young plants of onion (Allium cepa). Meldinger fra Norges Landbrukshøgskole 62:1-17.

Brewster, J.L. 1990. Physiology of crop growth and bulbing, p. 53-88. In: H.D. Rabinowitch and J.L. Brewster (eds.). Onions and allied crops. vol. I. CRC Press, Boca Raton, Fla.

Corgan, J.N. and N. Kedar. 1990. Onion culture in subtropical climates, p. 3147. In: H.D. Rabinowitch and J.L. Brewster (eds.). Onions and allied crops. vol. II. CRC Press, Boca Raton, Fla.

Grandberry, D.M., W.J. McLaurin, and W.O. Chance. 1990. Dry bulb onions. Georgia Coop. Ext. Serv. Hort. Circ. 801

Larsen, A. 1978. Freezing tolerance in grasses. Meldinger fra Norges Landbrukshøgskole. 57:156.

Martin, C.A. and D.L. Ingram. 1992. Simulation modeling of temperatures in root container media. J. Amer. Soc. Hort. Sci. 117:571-577.

Palta, J.P., J. Levitt, E.J. Stadelmann, and M.J. Burke. 1977. Dehydration of onion cells: A comparison of freezing vs. desiccation and living vs. dead cells. Physiol. Plant. 41:273-279.

Peffley, E.B., M. Ortiz, and J.N. Corgan. 1981. A technique for onion cold hardiness evaluation: Effects of plant age and size on hardiness. HortScience 16:773-774.

Rivers-Figueroa, C.H. 1991. Effects of soil texture, soil moisture level, and depth of planting on onion freeze injury. MS Thesis, New Mexico State Univ., Las Cruces.

Ruffner, J.A. and F.E. Bair. 1985. Weather of U.S. cities: City reports Alabama-Missouri. vol. I. 2nd ed. Gale Research Co., Detroit.

Sakai, A. and F. Yoshie. 1984. Freezing tolerance of ornamental bulbs and corms. J. Jpn. Soc. Hort. Sci. 52:445-449. 